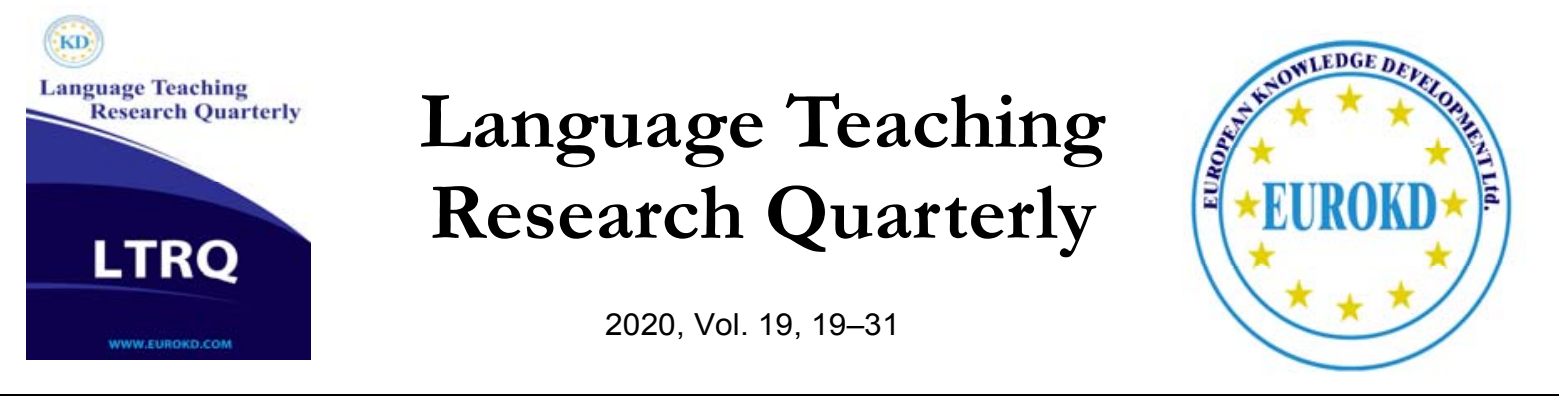

\title{
Helping to Maximize Learners' Motivation for Second Language Learning
}

\author{
Kata Csizér*, Éva Illés \\ Eötvös Loránd University, Budapest, Hungary \\ Special Issue: Pathways to the Successful Teaching and Learning of an L2 \\ In Honor of Andrew Cohen's Contributions to L2 Teaching and Learning Research
}

Received 15 November 2019 Accepted 25 April 2020

\begin{abstract}
Second language (L2) motivation research has been thriving for the past decades by emphasizing L2 motivation theories and describing the motivated learner, while relatively few studies have dealt with how to motivate students in a systematic way. Approaches in these studies either included investigations into the role of different motivational strategies that teachers can use to motivate their students (Dörnyei \& Csizér, 1998; Guilloteaux \& Dörnyei, 2008) or the impact of various intervention methods (Chan, 2014; Mackay, 2014; Magid, 2014). Even though more situated and classroom-room related projects have been completed recently (Henry, Sundqvist \& Thorsen, 2019), there is a need to provide further systematic analyses of how to maximize learner's L2 motivation in the 21 st century. To fulfill this aim, the present theoretical investigation first summarizes the most important L2 motivation theories and their contributions to learner motivation, then outlines the challenges that make motivating students difficult in the 21stcentury. These areas comprise the role of English as a lingua franca, students' plurilingual identities and the relationship between student motivation and autonomy as a user. Among the main results and implications of the investigation features the finding that student motivation can be increased by engaging learners on their own terms and by involving their reality and creativity in the language learning process. Methods and activities which enable students to act as L2 users in the language class include translation and literature. In addition, the classroom as a venue of genuine communication can have a positive impact on student motivation in the practice of language teaching.
\end{abstract}

Keywords: L2 motivation, English as a lingua franca, plurilingual identities, language learning autonomy 


\section{Introduction}

Learning and teaching in the 21 st century have brought about a number of challenges, and foreign language learning and teaching is no exception (Illés, in press). Providing guidance to teachers as to how to motivate their students through developing motivational strategies based on international research (e.g., Dörnyei, 2001) can be considered problematic at this point. As Henry and his colleagues point out "the unique nature of the local contexts in which teaching takes place means that challenges facing teachers of English in developing a motivational practice need to be understood in relation to locally-pertaining conditions" (Henry, Sundqvist \& Thorsen, 2019, p. 14). Another difficulty language teachers are facing is the changing nature and position of the language they teach in the face of the emergence of English as a lingua franca (ELF) in non-native contexts with its own set of challenges (Illés, in press). Therefore, we do not set out to provide a list of motivational strategies (e.g., Csizér, 2017; Dörnyei, 2001) that might or might not work in various contexts but present the results of a theoretical piece of research that first outlines some of the most relevant L2 motivation theories, then summarizes the challenges that practitioners face. After taking stock, we present our arguments that motivationally sensitive classroom teaching should take into account both the role of translation in teaching students who are by definition plurilingual individuals, as well as the potential impact of using literature in developing students' autonomy, relatedness and competence (Ryan \& Deci, 2017), and thus their long-term motivation. The main line of argument takes the reader from the theoretical perspectives all the way to practical implications, so both theoreticians and practitioners can find issues of interest to them.

\section{Motivational Theories}

Second language motivation research has been a multidisciplinary field informed by a number of different theories adapted from social science research. Based on a review of Lamb, Csizér, Henry and Ryan (2020), three main theoretical considerations seem to be relevant when motivational practices are investigated. In what follows, we will summarize these theoretical issues including the role of attitudes, self-related issues and self-determination theory.

\section{The role of attitudes in shaping L2 motivation}

It was Robert Gardner's pioneering research in multilingual Canada that has called attention to the socio-psychological fact that attitudes shape behavior, and this is not different for L2 learning. Students' dispositions towards the language, its speakers and culture, that is, their attitudes, affect the amount of effort they are willing to invest into language learning and the satisfaction they derive from the process (Gardner, 2020). Gardner's theoretical assumptions about how language and learning-related attitudes affect motivation have been directly tested in multiple Canadian and European contexts (Gardner, 2020;Masgoret \& Gardner, 2003). Apart from measuring students' general attitudes towards language learning and their interest in foreign languages, additional macro-level issues have been regularly included in their studies, such as 
attitudes towards the language community and possible integration. This does not mean that classroom-level variables have been neglected, for example, attitudes related to teachers and courses are included in their studies.

Another strength of Gardner's socio-psychological approach to L2 motivation is that he has regularly operationalized achievement types of dependent variables in studies (Gardner, 2020), although they have missed possibly relevant variables, such as attitudes towards the coursebook or curriculum. Gardner's work has inspired similar large-scales studies in different monolingual contexts, where opportunities using the foreign language outside the classroom do not abound (e.g., Dörnyei, Csizér \& Németh, 2006). Investigating primary school students (aged 13/14), Dörnyei and his colleagues have established that attitudes are similarly important in such contexts as well, indicating that the lack of apparent L2 speaking communities does not downplay the important role attitudes play (Dörnyei \& Csizér, 2002; Dörnyei, Csizér \& Németh, 2006). Additional studies from various Asian settings have shown that attitudes play both direct and indirect roles in shaping students' intended efforts towards learning English (Taguchi, Magid \& Papi, 2009).Dealing with the role of attitudes, Al-Hoorie (2016a, 2016b) has researched unconscious motivation and the impact of implicit attitudes by juxtaposing them with explicit (i.e., conscious) attitudes. His results have not only indicated the important impact of implicit attitudes but he has also found that the congruence of explicit and implicit attitudes lead to more openness towards L2 speaking communities as well as to higher achievement.

Despite their importance, research into the various types of attitudes does not seem to abound in the field. This is proven by the fact that no systematic studies exist on the comparative analysis of attitudes towards the different aspects of the learning process. The latest handbook of L2 motivation (Lamb, Csizér, Henry \& Ryan, 2020) fails to contain a chapter on attitudes and their relation to L2 motivation. One possible explanation might be that attitudes are notoriously difficult to change and therefore attitude-related classroom work/intervention can pose unrealistic expectations on teachers.

\section{Self-related issues in L2 motivation}

The first self-related concept receiving attention as regards to L2 motivation research was selfconfidence. Linguistic self-confidence, a concept closely related to self-efficacy in motivational and educational psychology, has been introduced into L2 motivation research by Richard Clément (Clément, 1980; Clément, Gardner, \& Smythe, 1977). The main difference between self-confidence and self-efficacy is that although self-confidence has a cognitive component, it is largely a socially grounded construct as opposed to self-efficacy, which is entirely cognitive in nature (cf. Bandura, 1997). A further distinction is that self-confidence subsumes individuals' beliefs about their abilities to reach goals or finish tasks successfully, and concerns a generalized perception of one's coping potentials relevant to a range of tasks and subject domains. Selfefficacy, however, is more specific: it is always linked to a concrete task (see Dörnyei \& Kormos, 2000). 
As for the operationalization of linguistic self-confidence, it can be done in at least two ways. It can refer to the learning of a particular language (see, for example, research by Clément), or it can be measured as referring to L2 learning in a general sense (e.g., Dörnyei, et al., 2006). Studies on self-confidence have found that the main antecedents of self-confidence are the quality and quantity of social contact and that self-confidence impacts motivation in a direct way (Clément \& Kruidenier, 1985; Clément, Dörnyei \& Noels, 1994). In addition, further studies have investigated the indirect role of self-confidence in motivation and have shown that selfconfidence was closely linked to the amount of support students received from their milieu and that it indirectly impacts L2 motivation (Dörnyei, et al., 2006). In a more situated research approach, task-based motivation has established that self-confidence is related to complexity and the amount of output students produced (Kormos \& Dörnyei, 2004).

Research into Content and Language Integrated Learning (CLIL) has also linked motivation and self-confidence showing higher motivation and self-confidence in CLIL contexts (Hüttner et al., 2013) and very similar results have been presented in Computer Assisted Language Learning (CALL) as well (Henry \& Lamb, 2020). In a similar vein, studies measuring self-efficacy have also proven direct links between motivation and self-efficacy (Piniel \& Csizér, 2013) and its important role in task motivation has been highlighted (Kormos \& Wilby, 2020).

A large body of research has been generated by Dörnyei's $(2005,2009)$ L2 Motivational Self System. This model posits that students' L2 motivation is shaped by three variables: ideal L2 self, describing how students imagine themselves as language users in the future; ought to L2 self, to what extent students are aware of outside pressures related to language learning and language learning experience subsuming attitudes towards the classroom processes. As research pertaining to this model has been summarized recently elsewhere (Boo, Dörnyei \& Ryan, 2015; Csizér, 2020a), here we only underline the fact that the model has united both self-related aspects stemming from self-discrepancy research in psychology (Higgins, 1987) and attitudinal types of variable in language learning experiences (Csizér \& Kálmán, 2019), highlighting the situational aspects of self-related studies as has been excellently exemplified by Henry, Sundqvist and Thorsen (2019). More importantly, though, this model has inspired studies of plurilingual learners that have discovered how both negative and positive interferences shape the motivation when ideal L2 and L3 selves are taken into account (Csizér \& Lukács, 2010; Henry, 2011; Henry \& Cliffordson, 2013). Describing learners studying multiple languages led to the extension of ideal L2 self to the notion of ideal multilingual self (Henry, 2017; Ushioda, 2017).

There is no doubt that learners' selves impact on not only L2 motivation but the learning process as well, still there is no unified theory in L2 motivation which would take into account various selves and their roles in learning motivation. The problem is partly empirical and related to various measurement issues, and there are still missing pieces of the puzzle as not all selfrelated concepts have been included in the analyses of learners' L2 motivational characteristics (Csizér, 2020a). The full array of possible selves could be investigated as suggested by MacIntyre, Mackinnon and Clément (2009). Therefore, it is a future research task to map the 
interrelationships of selves, their development and impact on L2 motivation and subsequent achievement, as well as the role of various constructs shaping selves to be tapped into as well.

\section{The internalization of L2 motivation}

Self-determination theory has assumed that there is a continuum leading from more external types of motives or orientations, as they are called in this theory, to internal motivation and thus shaping the learning process. These orientations stem from the understanding that for human well-being three psychological needs have to be satisfied: competence, relatedness and autonomy (Ryan \& Deci, 2017). Although self-determination theory has its roots in psychology (Deci \& Ryan, 1985), Noels has been researching its relevance to second and foreign language learning and the three basic types of orientations - amotivation (i.e., the absence of motivation), internal motivation, and external motivation -have been mapped extensively in foreign language learning for various contexts and learners of various ages (Noels et al., 2020). As Noels and her colleagues (Noels et al., 2020) provided a comprehensive review of more than 300 studies dealing with the role of self-determination theory in foreign language learning, we would only like to highlight two important aspects of these studies here. First, researching various types of motivated learning behavior measures has consistently shown that self-determined intrinsic motivation correlates with achievement-types measures, but the role of external motivation is more limited. Second, the reason why this theory is highly relevant for motivating learners is that the different types of orientations on the continuum are not seen as divided but moving along this continuum is possible and encouraged as more internalized orientations are seen to lead to a higher level of engagement and long-term motivation. This internalization of motivation can be helped by teachers who support students' autonomy, competence and relatedness (Noels et al., 2020).

\section{Challenges for the 21st century}

Many of the challenges researchers, educators and learners face nowadays arise from the fact that English functions as a lingua franca worldwide that impacts not only the teaching of English but that of languages other than English (LOTEs). English as a lingua franca (ELF) does not comprise a variety but, rather, entails the use of English "among speakers of different first languages for whom English is the communicative medium of choice, and often the only option" (Seidlhofer, 2011, p. 7).Although in essence ELF represents the common use of language, it also has features which are specific to it (Mauranen, 2009). One distinguishing characteristic is that ELF users, who include both native and non-native speakers of the language, come from a wide variety of linguacultural backgrounds (Jenkins, 2009). Except for monolingual native speakers, participants in ELF contexts of use are bi- or plurilingual speakers who bring their different languages (native or non-natives ones), worldviews and norms of communication to ELF interactions. This means that in ELF communication the area of shared knowledge between interlocutors is necessarily smaller than between those speakers who share a language variety and with it the norms of communication to which they adhere. Since there are fewer linguistic 
and cultural assumptions that ELF users can take for granted, increased negotiation of meaning is necessary in order to achieve mutual understanding. For successful ELF communication, speakers also need to be aware of how they can best and most effectively exploit the knowledge and skills they have acquired when learning and using their languages. Since the majority of ELF interlocutors are bi- and plurilingual, they can and do indeed draw on their "multi-faceted multilingual repertoires in a fashion motivated by the communicative purpose and the interpersonal dynamics of the interaction" (Seidlhofer, 2009, p. 242).

The immense diversity of ELF users and contexts requires that ELF speakers demonstrate openness towards the many different individuals they engage with in communication on a particular occasion rather than towards a particular L2 speech community. In addition, participants' tolerance of otherness has to be accompanied with a readiness to handle the inherent unpredictability of ELF interaction. When creating and increasing the linguistic and schematic common ground, ELF users need to try to take the other interlocutor's perspective and adapt their way of speaking in a way that is attuned to the other party (Blokpoel et al., 2012). In other words, ELF speakers need to employ accommodation strategies where "speakers may organize their outputs to take into account the requirements of their listeners; listeners may select from this discourse and organize it according to the cognitive structures most easily available for comprehension" (Giles \& Coupland, 1991, p. 85). However, as has been pointed out above, by its nature ELF communication is like any other type of communication, but due to the smaller area of linguistic and cognitive common ground, "we see in ELF is the pragmatic process of communication live, in action, laid bare, so to speak - open to observation (Widdowson, 2015, p. 367). As a result, the study of ELF use can give a deeper insight not only into how other lingua francas function but into how people in general interact. ELF research can also inform the teaching of English and other languages, e.g., with regard to the importance of accommodation skills.

Inevitably, the dominant lingua franca function of English has important implications for language teaching and motivation. One consequence of ELF use for English language teaching (ELT) is that in the case of English, learners need to be prepared for being able to communicate with a diversity of ELF users rather than with the relatively well definable group of native speakers. This then requires that when learners step outside of the classroom, they can act as effective and confident language users who are capable of coping with the challenges ELF communication presents. In order for learners to become successful ELF speakers, the language classroom should create conditions which allow learners to function as language users who engage both linguistically and schematically when interacting in English. Additionally and preferably, the tasks learners as users have to perform should pose problems with which ELF speakers have to cope, such as the variability of participant constellations (Hülmbauer, 2009) and the highly dynamic nature of ELF interactions.

Another consequence of the dominant lingua franca use of English is its impact of learning and using LOTEs. As studies investigating plurilingual learners studying English and other L3s have indicated, learning English can negatively affect the learning of LOTE. Csizér and Lukács 
(2013), for example, showed that students who learnt English and German simultaneously at the time of the data collection in Hungary but learnt English as L2 or L3 and similarly, German as L2 or L3, depending on the order of starting times of learning these languages displayed different motivation profiles. Only those students lacked any negative interferences in their motivational profiles who began learning English first and later added German as a L3 to their studies. These results indicate that the preferred order to learning L2s in the Hungarian context is when the globally important English precedes the regionally relevant German.

\section{Implications for Motivation Research and ELT}

In terms of attitude-related research, the emergence of English as a lingua franca poses problems for teaching and researching alike, stemming from the fact that neither teachers nor researchers can predict future language use, which makes it difficult to research attitudes pertaining to English. With English being a pluricentric language whose dominant function is that of a lingua franca, items such as "I like English" which are used in various studies, raise the question of towards which English or whose English research participants express their attitudes. In terms of self-related studies, one particular challenge is that in many contexts learners often learn and use multiple languages and thus develop plurilingual selves. As has been shown above, the interaction of these selves does not always lead to positive impacts, which underlines the importance of plurilingual pedagogies. A further difficulty is that the selves are not constant and are bound to change as learners progress, and the more they learn of and about L2 and L3, the more the ideal L2 and L3 selves may alter moving, for instance, from an idealized native speaker to that of a multilingual non-native speaker. Such a change in the ideal self then necessarily implies a favorable attitude towards non-native uses of languages.

A study conducted into motivation with Hungarian teachers of various languages indicates that being able to function as an independent, confident and effective language user is seen as a strong motivational force for language learners (Csizér,2020b). This finding is in line with an amended definition of autonomy which proposes that learner autonomy should "include the ability to cope with the linguistic and schematic diversity, the fluidity, and the increased demand for negotiation that interaction international contexts of use presents" (Illés, 2012, p. 509). Autonomous learners of languages are competent language users who effectively exploit the linguistic and other resources at their disposal in order to cope with the demands of interactions in L2/L3under their own steam. A motivated language learner can thus be seen as a selfconfident language user whose positive disposition towards not only different varieties, uses and users of English but also LOTEs makes them willing to invest time and effort in language learning. Such learners seek opportunities to use L2 and L3 with both native and non-native speakers, and exploit the almost unlimited exposure the Internet offers these days. Self-efficacy in this respect relates equally to the performance of a concrete task and, through successful participation in many L2/L3 interactions, to the learning of L2/L3.

As has been indicated above, in order for learners to become autonomous language users with the capability to cope with the undefined eventualities of communication, the language 
classroom has to provide conditions where learners are made to solve problems that L2/L3 interactions present. One issue arising in this regard is that in many contexts L2/L3 learning is a classroom-based enterprise and autonomous language use is not encouraged by teachers as curriculum and exam-related pressures override the possible effects of implicit learning, and wash back effects define classroom learning (Öveges \& Csizér, 2018). While a strong case has been made for the role of autonomy in foreign language learning (Little, 1999), the specific ways in which it relates to other individual difference variables is generally overlooked in contexts where teacher-centred instruction is still prevalent. It must be noted here that in the ELT literature, teacher-centredness is often associated with frontal teaching, as opposed to learnercentredness which, among others, entails group- or pairwork. As Harmer (2007) explains: "Learner-centred classrooms and lessons (where the learners are doing most of the work, often in pairs and groups) are often seen as opposite to 'teacher-centred' lessons [...]. For many commentators, learner-centred teaching is preferable to teacher-fronted lessons [...]"(p. 58).

The assumption underpinning the preference for learner-centredness and pair/group work is that the more opportunities learners are given to speak, the more they use and consequently better learn the language. However, the increased amount of student talk does not necessarily guarantee that genuine language use takes place. Learners are involved in genuine language use if, as in situations outside of the classroom, they engage both linguistically and schematically during an interaction in L2/L3. Therefore, in order for teachers to create conditions of language use, they have to make sure that students activate their knowledge of the world when making meaning in L2/L3. In classroom practice, such engagement is often stifled, especially when it manifests itself in off-topic remarks or in language use that bends and breaks rules (Illés \& Akcan, 2016).

\section{Suggestions for Motivating Students}

The question that arises is then how it is possible to combine language learning with language use and thus motivate learners to become autonomous and competent L2/L3 users? Apart from exploiting the opportunities classroom interaction between teacher-learners and learners-learners present (Illés \& Akcan, 2016), the use of literature and translation has been suggested as a means of inducing learner engagement (Illés, 2011, 2012, in press; Seidlhofer, 2011; Widdowson, 2003). Literature enables learners not only to get involved on an individual level but it also allows them to develop the openness and tolerance towards otherness that L2/L3 communication requires. Widdowson (2004) outlines the reason for this as follows:

What is distinctive about literary texts $[\ldots]$ is that they provoke diversity by their very generic design in that they do not directly refer to social and institutionalized versions of reality but represent an alternative order that can only be individually apprehended. They focus [...] not on the social contours but on personal meanings. (p. 135)

Alternative reality and creative use of language, which are characteristic of literary discourse, can prepare learners for the unpredictability, variety and variability of L2/L3 communication, as 
well as helping them adopt a positive attitude towards languages and worldviews which might be new or alien to them. In addition, coping with the challenges literature poses necessarily involves both linguistic and schematic problem-solving. However, for literature to fulfill its potential, teachers have to make informed decisions regarding the literary works they select for a particular lesson with particular students on a particular occasion. A text which is relatable and engaging for one student or group of students may prove boring and impossible or difficult to relate to for another student or group. Similarly, if teachers impose their own or other authorities' interpretation of a literary piece on the students, the diversity of possible individual interpretations by the learners remains unexploited as the students are not encouraged to engage on their own terms. Therefore, what has been said in the Introduction about motivational practice in general, i.e., that it has to be designed in a way that meets specific local conditions (Henry et al., 2019), applies to the exploitation of literature in language teaching as well.

One of the reasons for the necessary localization and individualization of tasks, texts and methods is the fact that motivation is one of the individual differences. Since all students are different, "there is no generic classroom; in a sense, all classrooms are different. Real classrooms." (Widdowson, 2009, p. 241, emphasis in the original). As a consequence, the abstractions researchers work with and provide for teachers serve as a way of having teachers reflect on their teaching experience rather than serving as ready-made answers and to-be-adopted methods. Another point to be made in this respect is the marked differences presented by language teaching at various levels and contexts of education. Having students take their own motivational temperature at various moments while engaged in a given language task (Cohen \& Dörnyei, 2001) may prove an effective means for university students and older adults to see how their motivation fluctuates within and across different tasks (e.g., reading and expository versus a literary text). In compulsory education- where learning a foreign language is not always the students' choice and is one of several school subjects, the application of an instrument such as this one can be an option to be tested out. The reason for this context-dependent difference is that in school contexts, the problem teachers often face is sustaining learner motivation indirectly through learner-relevant content, tasks and activities on a daily basis.

The example that follows comes from one of the second author's many years of experience as a grammar school teacher, and aims to show how motivation and autonomy can be boosted by the teaching of literature. The popularity of the Harry Potter series had a great and very positive impact on the motivation of English language learners' in that many learners took up the challenge of reading the books in the original. The first book of the series was then the obvious choice at the time to be used as a resource to motivate learners to engage on their own terms. In the particular lesson, the students were organized into groups and worked on tasks that they signed up for according to their interests and preferences. For example, students who were good at drawing designed illustrations of various scenes in the book. This, and the description of some of the characters made it also possible to create information gap tasks where the students who were involved in other activities had to identify which scene was illustrated and which character was described. One group undertook the translation of an extract from the book, which was 
followed by a whole group discussion of the comparison of the students' version with the official translation. Somewhat surprisingly but rightly, after careful consideration the students' verdict favored the students' version.

The other type of activity which, by promoting learners' bi- and plurilingual selves, can motivate learners to become competent L2/L3 users is translation. One reason for this is that translation reflects the reality of the acquisition of a second and additional languages (Widdowson, 2003). In the case of English, it also demonstrates the reality of ELF contexts of use which are, by definition, multillingual (Jenkins, 2015). Tasks that require pragmatic involvement are particularly suitable for the classroom practice of how audience-orientedness and accommodation works in L2/L3 communication. The reason for this is that a source text is always produced with a particular purpose and intention in mind which the target readers of the original are supposed to recognize. If the translator wants to have a similar perlocutionary effect on the readers of the target text, they have to take the linguistic and schematic needs of this audience into consideration when working on the translation. Rendering, for example, a brochure from one language into another, the translator needs to step into the shoes of a wide range of L2/L3 users and try to adopt their perspective, rather than the viewpoint of the representatives of a specific native-speaker community, if they aim to make the information in the brochure both relevant and accessible for speakers of English and other languages (Illés, 2012).

\section{Conclusion}

The main conclusion of our study is that the 21 stcentury learner is a plurilingual learner by definition, and motivation should consider the wide variety of learners, learning contexts and contexts of use. This is not only relevant for how teachers motivate their learners but also for researchers when the theoretical underpinnings of L2 or L3 motivation are taken into consideration. Theories relevant for plurilingual learners of different ages in various contexts should be developed and, based on these theories, suggestions that teachers can and, in fact, should tailor for their own local context could be offered. The major contribution of ELF-related research for the practical aspect of language learning motivation is that the context of use should always be defining when motivating students. In short, future research should consider the variety and variability of learners, learning contexts and language uses.

\section{Acknowledgement}

The first author was supported by the NKFIH - 129149 research grant.

\section{References}

Al-Hoorie, A. H. (2016a). Unconscious motivation. Part I: Implicit attitudes toward L2 speakers. Studies in Second Language Learning and Teaching, 6(3), 423-454.

Al-Hoorie, A. H. (2016b). Unconscious motivation. Part II: Implicit attitudes and L2 achievement. Studies in Second Language Learning and Teaching, 6(4), 619-649.

Bandura, A. (1997). Self-efficacy: The exercise of control. New York, NY: Freeman. 
Blokpoel, M., van Kesteren, M., Stolk, A., Haselager, P., Toni, I., \& van Rooij, I. (2012). Recipient design in human communication: Simple heuristics or perspective taking? Frontiers in Human Neuroscience. Retrieved from https://www.ncbi.nlm.nih.gov/pmc/articles/PMC3457047/pdf/fnhum-06-00253.pdf

Boo, Z., Dörnyei, Z., \& Ryan, S. (2015). L2 motivation research 2005-2014: Understanding a publication surge and a changing landscape. System, 55, 145-157.

Chan, L. (2014). Effects of an imagery training strategy on Chinese university students' possible second language selves and learning experiences. In K. Csizér \& M. Magid (Eds.), The impact of self-concept on language learning (pp. 357-376). Bristol, UK: Multilingual Matters.

Clément, R. (1980). Ethnicity contact and communicative competence in a second language. In H. M. Giles, W. P. Robinson, \& P. M. Smith (Eds.), Language: Social psychological perspectives (pp. 147-154). Oxford, UK: Pergamon.

Clément, R., Dörnyei, Z., \& Noels, K. A. (1994). Motivation, self-confidence, and group cohesion in the foreign language classroom. Language Learning, 44, 417-448.

Clément, R., Gardner, R. C., \& Smythe, P. C. (1977). Motivational variables in second language acquisition: A study of francophones leaning English. Canadian Journal of Behavioral Science, 9, 123-133.

Clément, R., \& Kruidenier, B. G. (1985). Aptitude, attitude and motivation in second language proficiency: A test of Clément's model. Journal of Language and Social Psychology, 4, 21-37.

Cohen, A. D.,\& Dörnyei, Z. (2001). Taking my motivational temperature on a language task.In R. M. Paige, A. D. Cohen, B. Kappler, J. C. Chi\& J. P. Lassegard (Eds.),Maximizing study abroad (pp. 170-171). Minneapolis, MI: Center for Advanced Research on Language Acquisition, University of Minnesota.

Csizér, K. (2017). Motivation in the L2 classroom. In S. Loewen \& M. Sato (Eds), The Routledge handbook of instructed second language acquisition (pp. 418-432). London, UK: Routledge.

Csizér, K. (2020a). The L2 Motivational Self System. In M. Lamb, K. Csizér, A. Henry \& S. Ryan (Eds.), Palgrave Macmillan handbook of motivation for language learning (pp. 71-93). Basingstoke, UK: Palgrave.

Csizér, K. (2020b). Motivation to learn foreign languages and storytelling. In N. Camps-Casals, M. Canals Botines \& N. M. Casanovas (Eds), Storytelling revisited 2019: Music, language, gender, cinema (pp. 31-39). Vic, Spain: Servei de Publicacions de la Universitat de Vic - Universitat Central de Catalunya.

Csizér, K., \& Kálmán, Cs. (2019). Language learning experience: the neglected element in L2 motivation research. Studies in Second Language Learning and Teaching. Special Issue, 6(1).

Csizér, K., \& Lukács, G. (2010). The comparative analysis of motivation, attitudes and selves: The case of English and German in Hungary. System, 38, 1-13.

Deci, E. L., \& Ryan, R. M. (1985). Intrinsic motivation and self-determination in human behavior. New York, NY: Plenum Press.

Dörnyei, Z. (2001). Motivational strategies in the language classroom. Cambridge, UK: Cambridge University Press.

Dörnyei, Z. (2005). The psychology of the language learner: Individual differences in second language acquisition. Mahwah, NJ: Lawrence Erlbaum.

Dörnyei, Z. (2009). The L2 Motivational Self System. In Z. Dörnyei \& E. Ushioda (Eds.), Motivation, language identity and the L2 self (pp. 9-42). Bristol, UK: Multilingual Matters.

Dörnyei, Z., \& Csizér, K. (1998). Ten commandments for motivating language learners: Results of an empirical study. Language Teaching Research, 2, 203-229.

Dörnyei, Z., \& Csizér, K. (2002). Some dynamics of language attitudes and motivation: Results of a longitudinal nationwide survey. Applied Linguistics, 23, 421-462.

Dörnyei, Z., Csizér, K., \& Németh, N. (2006). Motivation, language attitudes and globalisation: A Hungarian perspective. Clevedon, UK: Multilingual Matters. 
Dörnyei, Z., \& Kormos, J. (2000). The role of individual and social variables in oral task performance. Language Teaching Research, 4, 275-300.

Gardner, R. C. (2020). The Socio-educational Model of second language acquisition. In M. Lamb, K. Csizér, A. Henry \& S. Ryan (Eds.), Palgrave Macmillan handbook of motivation for language learning (pp. 21-37). Basingstoke, UK: Palgrave.

Giles, H., \& Coupland, N. (1991). Language: Contexts and consequences. Milton Keynes, UK: Open University Press.

Guilloteaux, M. J., \& Dörnyei, Z. (2008). Motivating language learners: A classroom-oriented investigation of the effects of motivational strategies on student motivation. TESOL Quarterly, 42(1), 55-77.

Harmer, J. (2007). The practice of English language teaching (4th ed.). Harlow, UK: Pearson Education Limited.

Henry, A. (2011). Examining the impact of L2 English on L3 selves: A case study. International Journal of Multilingualism, 8, 235-255.

Henry, A. (2017). L2 motivation and multilingual identities. The Modern Language Journal, 101, 548-565.

Henry, A., \& Cliffordson, C. (2013). Motivation, gender, and possible selves. Language Learning, 63, $271-295$.

Henry, A., \& Lamb, M. (2020). L2 motivation and digital technologies. In M. Lamb, K. Csizér, A. Henry \& S. Ryan (Eds.), Palgrave Macmillan handbook of motivation for language learning (pp. 599-619). Basingstoke, UK: Palgrave.

Henry, A., Sundqvist, P. \& Thorsen, C., (2019). Motivational practice: Insights from the classroom. Lund, Sweden: Studentlitteratur.

Higgins, E. T. (1987). Self-discrepancy: A theory relating self and affect. Psychological Review, 94, 319-340.

Hülmbauer, C. (2009). 'We don't take the right way. We just take the way that we think you will understand' - The shifting relationship between correctness and effectiveness in ELF. In A. Mauranen \& E. Ranta (Eds.), English as a Lingua Franca: Studies and findings (pp. 323-347). Newcastle upon Tyne, England: Cambridge Scholars.

Hüttner, J., Dalton-Puffer, C., \& Smit, U. (2013). The power of beliefs: lay theories and their influence on the implementation of CLIL programmes. International Journal of Bilingual Education and Bilingualism, 16, 267284.

Illés, É. (2011). Communicative language teaching and English as a lingua franca. Vienna English Working Papers, 20(1), 3-16.

Illés, É. (2012). Learner autonomy revisited. ELT Journal, 66(4), 505-513.

Illés, É. (in press). Understanding context in language use and teaching: An ELF perspective. Abingdon, UK: Routledge.

Illés, É., \& Akcan, S. (2016). Bringing real-life language use into EFL classrooms. ELT Journal, 71(1), 3-12.

Jenkins, J. (2009). English as a lingua franca: Interpretations and attitudes. World Englishes, 28(2), 200-207.

Jenkins, J. (2015). Repositioning English and multilingulism in English as a lingua franca. Englishes in Practice, 2(3), 49-85.

Kormos, J., \& Dörnyei, Z. (2004). The interaction of linguistic and motivational variables in second language task performance. Zeitschrift für interkulturellen Fremdsprachenunterricht, 9, 2.

Kormos, J., \& Wilby, J. (2020). Task motivation. In M. Lamb, K. Csizér, A. Henry \& S. Ryan (Eds.), Palgrave Macmillan handbook of motivation for language learning (pp. 267-286). Basingstoke, UK: Palgrave.

Lamb, M., Csizér, K., Henry, A., \& Ryan, S. (Eds.) (2020). Palgrave Macmillan handbook of motivation for language learning. Basingstoke, UK: Palgrave. 
Little, D. (1999) Learner autonomy is more than a Western cultural construct. In S. Cotterall \& D. Crabbe (Eds.), Learner Autonomy in Language Learning: Defining the Field and Effecting Change (pp. 11-18). Frankfurt am Main, Germany: Peter Lang.

MacIntyre, P.D., Mackinnon, S.P., \& Clément, R. (2009). Toward the development of a scale to assess possible selves as a source of language learning motivation. In Z. Dörnyei \& E. Ushioda (Eds.), Motivation, language identity and the L2 self (pp. 193-214). Clevedon, UK: Multilingual Matters.

Mackay, J. (2014). Applications and implications of the L2 Motivational Self System in a Catalan EFL context. In K. Csizér \& M. Magid (Eds.), The impact of self-concept on language learning (pp. 377-400). Bristol, UK: Multilingual Matters.

Magid, M. (2014). A motivational programme for learners of English: An application of the L2 Motivational Self System. In K. Csizér \& M. Magid (Eds.), The impact of self-concept on language learning (pp. 333-356). Bristol, UK: Multilingual Matters.

Masgoret, A.-M., \& Gardner, R. C. (2003). Attitudes, motivation, and second language learning: A meta-analysis of studies conducted by Gardner and Associates. Language Learning, 53, 123-163.

Mauranen, A. (2009). Chunking in ELF: Expressions for managing interaction. Intercultural Pragmatics, 6(2), 217233.

Noels, K. A., Lou N. M., Vargas Lascano, D. I., Chaffee, K. E., Dincer, A., Zhang Y. S. D., \&Zhang, X. (2020). Self-determination and motivated engagement in language learning. In M. Lamb, K. Csizér, A. Henry \& S. Ryan (Eds.), Palgrave Macmillan handbook of motivation for language learning (pp. 95-115). Basingstoke, UK: Palgrave.

Öveges, E., \& Csizér, K. (Eds.) (2018). Vizsgálat a köznevelésben folyó idegennyelv-oktatás kereteiröl és hatékonyságáról: Kutatási jelentés. [Investigation of the context and efficiency of foreign language teaching in public education: Research report]. Budapest, Hungary: Oktatási Hivatal.

Piniel, K., \& Csizér, K. (2013). L2 motivation, anxiety and self-efficacy: The interrelationship of individual variables in the secondary school context. Studies in Second Language Learning and Teaching, 3(4), 523-546.

Ryan, R. M., \& Deci, E. L. (2017). Self-determination theory: Basic psychological needs in motivation, development, and wellness. New York, NY: Guilford.

Seidlhofer, B. (2009). Common ground and different realities: World Englishs and English as a lingua franca. World Englishes 28(2), 236-245.

Seidlhofer, B. (2011). Understanding English as a lingua franca. Oxford, England: Oxford University Press.

Taguchi, T., Magid, M., \& Papi, M. (2009). The L2 Motivational Self System among Japanese, Chinese and Iranian Learners of English: A Comparative Study. In Z. Dörnyei, \& E. Ushioda (Eds.), Motivation, Language Identity and the L2 Self (pp. 66-97). Bristol, UK: Multilingual Matters.

Ushioda, E. (2017). The impact of Global English on motivation to learn other languages: Towards an ideal multilingual self. The Modern Language Journal, 101, pp. 469-482.

Widdowson, H. G. (2003). Issues in English language teaching. Oxford, UK: Oxford University Press.

Widdowson, H. G. (2004). Text, context, pretext. Oxford, England: Blackwell.

Widdowson, H. G. (2009). Coming to terms with reality. In R. Bhanot \& E. Illes (Eds.), The best of Language Issues (pp. 240-244). London, UK: LLU+ London South Bank University.

Widdowson, H. G. (2015). ELF and the pragmatics of language variation. Journal of English as a lingua franca, $4(2), 359-372$. 